Anastasiia Samoilikova,

Ph.D, Sumy State University, Ukraine

(iD) ORCID ID, 0000-0001-8639-5282

email:av.samoilikova@finance.sumdu.edu.ua

Rosen Kunev,

Director, Vazhod-2019 Ltd, Sofia, Bulgaria

Correspondence author: av.samoilikova@finance.sumdu.edu.ua

\title{
THE IMPACT OF HEALTH CARE FINANCING ON THE ECONOMIC GROWTH: EU COUNTRIES ANALYSIS
}

Abstract. This article generalized modern tendencies and actual peculiarities of health care financing. The key aim of the research is to investigate the dynamics of health care financing as a factor of economic growth based on EU countries analysis. Systematization information sources connected with health care financing and its structure indicate that the EU countries analysis of dynamics of health care financing and its impact on economic growth was conducted fragmentary. This issue is still actual both for scholars and policymakers, especially for Ukraine, based on European trends. Investigation in the article is made according to the following stages: 1) introduction and relevance grounding; 2) literary review and identifying the necessity of research in this scientific area; 3) describing methodology, research methods, and current hypothesis; 4) characteristic of research results and confirming the hypothesis of the positive impact of the health care financing on economic growth; 5) making conclusions. Methodological tools of the research methods were structural and comparative analysis, logical generalization, and scientific abstraction. The methods of cross-country statistical and analytical analysis using the Excel 2010 software package for the sample from 14 EU countries for 2009-2018 (limited number of countries and limited data in 2018 relate to the data availability on open website of the EU statistical office) were applied to analyse the structure of health care financing, in particular financing schemes, main providers, and health care functions. The top countries in health care financing were identified. The methods of empirical analysis using the STATA software package for this data sample were used to confirm the hypothesis about the positive impact of the health care financing on economic growth - the GDP per capita. The nature of the analysed indices distribution was estimated based on results of Shapiro-Wilk test. So, Pearson or Spearman correlation coefficient was chosen. The statistical significance and strength of the relationship between the indicators of total expenditure for health care, and in particular government financing and compulsory contributory health care financing, voluntary health care financing, and household out-of-pocket payment for health care and the change of GDP per capita were assessed through a correlation analysis. The time lags of achievement the most statistical significance by this relationship was also identified. The results of the research show that the impact of health care financing on the change of economic growth is very high in 12 from 14 investigated EU countries (with lags of 1-3 years) and high in 2 from 14 countries (with a lag of 1 year). The character of this relationship for the most countries (9 from 14 countries) is direct (positive), and for 5 countries it is inverse (negative). The results of the research will be useful during future fundamental and practical research connected with health care financing and its modelling, for scholars and government officials to reform the health care system and its financial mechanism.

Keywords: economic growth, expenditure for health care, GDP per capita, government health care financing, health care, health insurance, household health payment, provider of health care, voluntary health care financing.

Introduction. With the rapid spread of the coronavirus pandemic and its negative consequences, doctors, scientists, and government officials have faced new challenges and targets. One of the priorities is to reform the state policy in the field of health care. Health care financing is an essential part of this policy, it is critical for reaching health coverage.

The World Health Organization advises countries to develop responsive and resilient health systems that are centred on people's needs and circumstances, backed by adequate funding, strong health plans and evidence-based policies (WHO, Health systems financing). In this context, the EU experience is useful

Cite as: Samoilikova, A., \& Kunev, R. (2020). The Impact of Health Care Financing on the Economic Growth: EU Countries Analysis. Health Economics and Management Review, 2, 24-32. http://doi.org/10.21272/hem.2020.2-03 
for many developing countries, especially for Ukraine. Despite much research in this scientific sphere, the impact of health care financing on the change of GDP per capita is covered fragmentary and needed the empirical confirmation.

Thus, the paper aims to investigate the dynamics of health care financing as a driver of economic growth based on EU countries' analysis.

Literature Review. Many scholars have studied the problem of health care and its different aspects. The appropriate role of the state in health was proved by Musgrove (1996). White (2001) characterized the future form of health care financing, being sure that modern e-health projects and the contribution approach could improve a financing system that rewards doctors who offer quality service and care. Schieber et al. (2006) assessed health financing policy in low- and middle-income countries, discussed the essential functions of health financing systems and the various mechanisms for effective revenue collection, pooling of resources, and purchasing interventions.

Alkaravani (2014) identified the characteristics of the quality level of medical services and their marketing. Fan and Savedoff (2014) paid attention on health financing transition to provide a conceptual framework for understanding health markets and public policy. Bagmet and Obeid (2017) analysed the financial providing of social protection comparing Ukraine and the EU countries. Cylus et al. (2018) emphasized that health system is an essential macroeconomic link, a provider of many jobs, and a driver of a labor force.

Antosova et al. (2019) showed healthcare availability in households with different income levels, studied public healthcare expenditure and R\&D expenditure in this sphere. Stepovic (2019) analysed GDP growth and health care expenditures worldwide and proposed to make government investments in health as large as countries can afford due to the population aging, non-communicable disease and treatment, and pharmacological innovations. Yelnikova and Kwilinski (2020) investigated the implementation of impact-investing in the health care system and its comparison with other traditional investment mechanisms considering the socially responsible public investment policy.

Systematization of these and other literary sources to describe the problem of health care financing indicates that the EU countries' analysis of dynamics of health care financing and its impact on economic growth was conducted fragmentary. This issue is still actual both for scholars and policymakers, especially for Ukraine, based on European trends.

Methodology and research methods. Methodological tools of the research methods include structural and comparative analysis, logical generalization, scientific abstraction. Cross-country statistical and analytical analysis based on the Excel 2010 in 14 EU countries for 2009-2018 (limited number of countries and limited data in 2018 relate to the data available on open website of the EU statistical office) were applied to analyze the structure of health care financing, in particular financing schemes, main providers, health care functions.

The correlation analysis based on the STATA software for these EU countries was applied to confirm the hypothesis on the positive impact of the health care financing on economic growth - the change of GDP per capita. The nature of the analysed indices distribution was estimated based on results of ShapiroWilk test (Shapiro and Wilk, 1965). Then Pearson (for normal distribution) or Spearman (in case of absence of normal distribution) correlation coefficient was chosen (Pearson, 1896; Spearman, 1904). The statistical significance and strength of the relationship between the indicators of total expenditure for health care, and in particular government financing and compulsory contributory health care financing, voluntary health care financing, and household out-of-pocket payment for health care and the change of GDP per capita were assessed through a correlation analysis. The time lags of achievement the most statistical significance by this relationship was also identified.

Results. Health care financing includes direct payments by households and third-party financing through which citizens obtain health services (Eurostat, 2020). The main ones are the following: 1) government financing, compulsory contributory health insurance, social health insurance and compulsory private insurance schemes; 2) voluntary health insurance, non-profit institutions financing and 
enterprise financing schemes; 3) household out-of-pocket payment; 4) resident abroad financing and other financing schemes.

Health care financing covers the following health care functions: rehabilitative care, curative care, inpatient care, outpatient care, daycare, long-term care (health), home-based care, ancillary services, therapeutic appliances, pharmaceuticals, medical goods, preventive care, and governance. Accordingly, leading health care providers are residential long-term care facilities, hospitals, providers of ancillary services, providers of ambulatory healthcare, providers of medical goods and preventive care, healthcare administration etc (Eurostat, 2020).

To investigate health care financing and expenditure structure the authors made the sample from 14 EU countries for 2009-2018 (limited number of countries and limited data in 2018 relate to the data available on the website of the EU statistical office). Total expenditure for health care in these countries is presented in Table 1.

Table 1. Total expenditure for health care, $\%$ of GDP

\begin{tabular}{lcccccccccc}
\hline \multicolumn{1}{c}{ Country } & $\mathbf{2 0 0 9}$ & $\mathbf{2 0 1 0}$ & $\mathbf{2 0 1 1}$ & $\mathbf{2 0 1 2}$ & $\mathbf{2 0 1 3}$ & $\mathbf{2 0 1 4}$ & $\mathbf{2 0 1 5}$ & $\mathbf{2 0 1 6}$ & $\mathbf{2 0 1 7}$ & $\mathbf{2 0 1 8}$ \\
\hline Austria & 10,23 & 10,22 & 10,03 & 10,20 & 10,29 & 10,37 & 10,37 & 10,36 & 10,36 & 10,32 \\
Belgium & 10,36 & 10,23 & 10,39 & 10,51 & 10,56 & 10,44 & 10,43 & 10,28 & 10,41 & 10,32 \\
Cyprus & 6,52 & 6,52 & 6,45 & 6,55 & 6,95 & 6,96 & 6,93 & 6,83 & 6,74 & 6,77 \\
Denmark & 10,33 & 10,33 & 10,15 & 10,24 & 10,17 & 10,17 & 10,23 & 10,14 & 10,12 & 10,10 \\
Estonia & 6,51 & 6,27 & 5,77 & 5,79 & 5,98 & 6,08 & 6,35 & 6,50 & 6,61 & 6,66 \\
Finland & 9,16 & 9,14 & 9,22 & 9,59 & 9,81 & 9,78 & 9,65 & 9,38 & 9,14 & 9,04 \\
France & 11,30 & 11,24 & 11,20 & 11,31 & 11,44 & 11,58 & 11,47 & 11,50 & 11,39 & 11,26 \\
Germany & 11,24 & 11,10 & 10,78 & 10,85 & 10,99 & 11,02 & 11,16 & 11,23 & 11,37 & 11,47 \\
Greece & 9,41 & 9,52 & 9,03 & 8,79 & 8,32 & 7,85 & 8,02 & 8,21 & 7,97 & 7,72 \\
Hungary & 7,25 & 7,52 & 7,54 & 7,47 & 7,26 & 7,09 & 6,97 & 7,05 & 6,79 & 6,70 \\
Lithuania & 7,36 & 6,83 & 6,51 & 6,29 & 6,14 & 6,20 & 6,49 & 6,64 & 6,47 & 6,57 \\
Netherlands & 9,99 & 10,16 & 10,23 & 10,54 & 10,58 & 10,57 & 10,32 & 10,25 & 10,06 & 9,97 \\
Portugal & 9,88 & 9,84 & 9,53 & 9,35 & 9,08 & 9,02 & 8,98 & 9,42 & 9,33 & 9,45 \\
Spain & 9,11 & 9,12 & 9,17 & 9,16 & 9,07 & 9,09 & 9,13 & 8,95 & 8,94 & 8,99 \\
\hline
\end{tabular}

Source: developed by the author based on (Eurostat Data, Expenditure for selected health care providers by health care financing schemes, 2009-2018).

The top countries in health care financing are Germany, France, Austria, Belgium, and Denmark (the share of the expenditure is more than $10 \%$ of GDP). The main elements of healthcare expenditure include government financing and compulsory contributory health care financing, voluntary health care financing, household out-of-pocket payment for health care, and others. Let us analyze these three expenditure components.

Government financing and compulsory contributions are shown in Table 2.

Table 2. Government financing and compulsory contributions, \% of GDP

\begin{tabular}{lrrrrrrrrrr}
\hline \multicolumn{1}{c}{ Country } & $\mathbf{2 0 0 9}$ & $\mathbf{2 0 1 0}$ & $\mathbf{2 0 1 1}$ & $\mathbf{2 0 1 2}$ & $\mathbf{2 0 1 3}$ & $\mathbf{2 0 1 4}$ & $\mathbf{2 0 1 5}$ & $\mathbf{2 0 1 6}$ & $\mathbf{2 0 1 7}$ & $\mathbf{2 0 1 8}$ \\
\hline Austria & 7,68 & 7,63 & 7,48 & 7,62 & 7,61 & 7,67 & 7,68 & 7,66 & 7,66 & 7,71 \\
Belgium & 7,88 & 7,79 & 7,90 & 8,03 & 8,03 & 7,92 & 7,90 & 7,82 & 7,90 & 7,82 \\
Cyprus & 3,01 & 3,01 & 3,09 & 3,04 & 3,20 & 3,00 & 2,88 & 2,81 & 2,79 & 2,91 \\
Denmark & 8,67 & 8,67 & 8,49 & 8,60 & 8,57 & 8,56 & 8,61 & 8,53 & 8,50 & 8,48 \\
Estonia & 5,07 & 4,79 & 4,42 & 4,44 & 4,52 & 4,60 & 4,80 & 4,92 & 4,87 & 4,91 \\
Finland & 7,10 & 7,05 & 7,16 & 7,49 & 7,64 & 7,63 & 7,42 & 7,15 & 6,99 & 6,95 \\
France & 8,65 & 8,58 & 8,52 & 8,61 & 8,72 & 8,86 & 8,79 & 9,55 & 9,48 & 9,42 \\
Germany & 9,37 & 9,24 & 8,96 & 9,00 & 9,21 & 9,28 & 9,40 & 9,47 & 9,61 & 9,70 \\
\hline
\end{tabular}


Continued Table 2

\begin{tabular}{cllllllllll}
\hline Greece & 6,43 & 6,56 & 5,93 & 5,81 & 5,13 & 4,53 & 4,62 & 4,99 & 4,82 & 4,53 \\
Hungary & 4,95 & 5,05 & 5,02 & 4,89 & 4,84 & 4,76 & 4,75 & 4,80 & 4,70 & 4,65 \\
Lithuania & 5,33 & 4,90 & 4,62 & 4,24 & 4,06 & 4,19 & 4,36 & 4,42 & 4,28 & 4,40 \\
Netherlands & 8,31 & 8,47 & 8,46 & 8,65 & 8,59 & 8,57 & 8,40 & 8,32 & 8,21 & 8,19 \\
Portugal & 6,91 & 6,86 & 6,45 & 6,13 & 6,07 & 5,96 & 5,94 & 5,79 & 5,70 & 5,81 \\
Spain & 6,84 & 6,79 & 6,74 & 6,60 & 6,44 & 6,39 & 6,51 & 6,41 & 6,32 & 6,33 \\
\hline
\end{tabular}

Source: developed by the author based on (Eurostat Data, Expenditure for selected health care providers by health care financing schemes, 2009-2018).

The highest level of government financing is in Germany, France, and Denmark. The comparison of voluntary health care financing is presented in Table 3.

Table 3. Voluntary health care financing, $\%$ of GDP

\begin{tabular}{ccccccccccc}
\hline Country & $\mathbf{2 0 0 9}$ & $\mathbf{2 0 1 0}$ & $\mathbf{2 0 1 1}$ & $\mathbf{2 0 1 2}$ & $\mathbf{2 0 1 3}$ & $\mathbf{2 0 1 4}$ & $\mathbf{2 0 1 5}$ & $\mathbf{2 0 1 6}$ & $\mathbf{2 0 1 7}$ & $\mathbf{2 0 1 8}$ \\
\hline Austria & 0,70 & 0,69 & 0,67 & 0,68 & 0,70 & 0,71 & 0,71 & 0,70 & 0,71 & 0,72 \\
Belgium & 0,41 & 0,41 & 0,43 & 0,43 & 0,45 & 0,46 & 0,49 & 0,51 & 0,52 & 0,53 \\
Cyprus & 0,68 & 0,68 & 0,67 & 0,72 & 0,75 & 0,80 & 0,90 & 0,87 & 0,88 & 0,84 \\
Denmark & 0,18 & 0,18 & 0,19 & 0,19 & 0,20 & 0,21 & 0,22 & 0,22 & 0,23 & 0,24 \\
Estonia & 0,12 & 0,11 & 0,10 & 0,10 & 0,11 & 0,10 & 0,10 & 0,11 & 0,11 & 0,12 \\
Finland & 0,38 & 0,38 & 0,39 & 0,42 & 0,42 & 0,43 & 0,43 & 0,42 & 0,41 & 0,42 \\
France & 1,50 & 1,52 & 1,54 & 1,56 & 1,58 & 1,58 & 1,57 & 0,85 & 0,82 & 0,80 \\
Germany & 0,33 & 0,33 & 0,33 & 0,33 & 0,33 & 0,32 & 0,32 & 0,32 & 0,32 & 0,34 \\
Greece & 0,20 & 0,27 & 0,27 & 0,29 & 0,28 & 0,31 & 0,32 & 0,34 & 0,34 & 0,36 \\
Hungary & 0,39 & 0,41 & 0,40 & 0,38 & 0,36 & 0,32 & 0,30 & 0,30 & 0,26 & 0,24 \\
Lithuania & 0,05 & 0,04 & 0,05 & 0,05 & 0,05 & 0,06 & 0,06 & 0,07 & 0,08 & 0,08 \\
Netherlands & 0,77 & 0,76 & 0,80 & 0,82 & 0,77 & 0,77 & 0,76 & 0,78 & 0,73 & 0,71 \\
Portugal & 0,54 & 0,56 & 0,57 & 0,59 & 0,55 & 0,56 & 0,55 & 0,84 & 0,84 & 0,84 \\
Spain & 0,54 & 0,48 & 0,56 & 0,56 & 0,56 & 0,60 & 0,58 & 0,58 & 0,65 & 0,67 \\
\hline
\end{tabular}

Source: developed by the author based on (Eurostat Data, Expenditure for selected health care providers by health care financing schemes, 2009-2018).

The share of voluntary health care financing is significantly less than governmental. The highest level is in Portugal, Cyprus, and France - about $0,8 \%$. And household out-of-pocket payment for health care are shown in Table 4.

Table 4. Household out-of-pocket payment for health care, \% of GDP

\begin{tabular}{lrrrrrrrrrr}
\hline \multicolumn{1}{c}{ Country } & $\mathbf{2 0 0 9}$ & $\mathbf{2 0 1 0}$ & $\mathbf{2 0 1 1}$ & $\mathbf{2 0 1 2}$ & $\mathbf{2 0 1 3}$ & $\mathbf{2 0 1 4}$ & $\mathbf{2 0 1 5}$ & $\mathbf{2 0 1 6}$ & $\mathbf{2 0 1 7}$ & $\mathbf{2 0 1 8}$ \\
\hline Austria & 1,85 & 1,90 & 1,88 & 1,90 & 1,97 & 1,98 & 1,98 & 1,99 & 1,98 & 1,89 \\
Belgium & 2,06 & 2,04 & 2,06 & 2,05 & 2,09 & 2,06 & 2,03 & 1,95 & 1,98 & 1,97 \\
Cyprus & 2,81 & 2,81 & 2,67 & 2,78 & 2,96 & 3,14 & 3,10 & 3,15 & 3,07 & 3,02 \\
Denmark & 1,49 & 1,49 & 1,48 & 1,45 & 1,40 & 1,40 & 1,40 & 1,39 & 1,39 & 1,39 \\
Estonia & 1,32 & 1,38 & 1,24 & 1,25 & 1,35 & 1,38 & 1,45 & 1,47 & 1,64 & 1,64 \\
Finland & 1,68 & 1,72 & 1,67 & 1,67 & 1,74 & 1,73 & 1,80 & 1,81 & 1,74 & 1,67 \\
France & 1,15 & 1,15 & 1,15 & 1,14 & 1,14 & 1,14 & 1,11 & 1,10 & 1,09 & 1,04 \\
Germany & 1,54 & 1,53 & 1,49 & 1,52 & 1,45 & 1,42 & 1,45 & 1,45 & 1,44 & 1,43 \\
Greece & 2,78 & 2,69 & 2,81 & 2,68 & 2,83 & 2,91 & 2,95 & 2,87 & 2,79 & 2,81 \\
Hungary & 1,90 & 2,06 & 2,13 & 2,19 & 2,06 & 2,01 & 1,91 & 1,95 & 1,83 & 1,80 \\
Lithuania & 1,97 & 1,89 & 1,84 & 2,00 & 2,01 & 1,95 & 2,07 & 2,14 & 2,11 & 2,08 \\
Netherlands & 0,91 & 0,92 & 0,97 & 1,06 & 1,22 & 1,22 & 1,17 & 1,16 & 1,11 & 1,08 \\
\hline
\end{tabular}


Continued Table 4

\begin{tabular}{lllllllllll}
\hline Portugal & 2,43 & 2,42 & 2,51 & 2,64 & 2,45 & 2,50 & 2,49 & 2,79 & 2,79 & 2,79 \\
Spain & 1,73 & 1,85 & 1,87 & 2,00 & 2,06 & 2,10 & 2,03 & 1,97 & 1,98 & 1,99 \\
\hline
\end{tabular}

Source: developed by the author based on (Eurostat Data, Expenditure for selected health care providers by health care financing schemes, 2009-2018).

To investigate the dynamics of health care financing as a factor of economic growth we also need to generalise and analyse GDP data (Table 5).

Table 5. GDP at market prices, percentage change on previous period, per capita, $\%$

\begin{tabular}{lcccccccccc}
\hline \multicolumn{1}{c}{ Country } & $\mathbf{2 0 0 9}$ & $\mathbf{2 0 1 0}$ & $\mathbf{2 0 1 1}$ & $\mathbf{2 0 1 2}$ & $\mathbf{2 0 1 3}$ & $\mathbf{2 0 1 4}$ & $\mathbf{2 0 1 5}$ & $\mathbf{2 0 1 6}$ & $\mathbf{2 0 1 7}$ & $\mathbf{2 0 1 8}$ \\
\hline Austria & $-4,00$ & 1,60 & 2,60 & 0,20 & $-0,60$ & $-0,10$ & 0,00 & 0,70 & 1,80 & 2,10 \\
Belgium & $-2,80$ & 1,90 & 0,40 & 0,10 & 0,00 & 1,10 & 1,50 & 0,80 & 1,20 & 1,30 \\
Cyprus & $-4,60$ & $-0,60$ & $-2,10$ & $-4,90$ & $-6,30$ & $-0,70$ & 3,80 & 6,00 & 4,20 & 4,00 \\
Denmark & $-5,40$ & 1,40 & 0,90 & $-0,10$ & 0,50 & 1,10 & 1,60 & 2,40 & 2,20 & 1,70 \\
Estonia & $-14,30$ & 2,90 & 7,70 & 3,50 & 1,70 & 3,30 & 2,00 & 3,00 & 5,50 & 4,10 \\
Finland & $-8,50$ & 2,70 & 2,10 & $-1,90$ & $-1,40$ & $-0,80$ & 0,20 & 2,50 & 3,00 & 1,20 \\
France & $-3,40$ & 1,40 & 1,70 & $-0,20$ & 0,10 & 0,50 & 0,70 & 0,70 & 1,90 & 1,50 \\
Germany & $-5,40$ & 4,40 & 3,90 & 0,20 & 0,20 & 1,80 & 0,60 & 1,40 & 2,20 & 1,00 \\
Greece & $-4,60$ & $-5,60$ & $-10,00$ & $-6,60$ & $-2,00$ & 1,40 & 0,20 & $-0,10$ & 1,50 & 1,80 \\
Hungary & $-6,60$ & 1,40 & 2,20 & $-0,90$ & 2,10 & 4,50 & 4,10 & 2,40 & 4,60 & 5,50 \\
Lithuania & $-13,90$ & 3,80 & 8,50 & 5,20 & 4,60 & 4,40 & 3,00 & 3,80 & 5,80 & 4,90 \\
Netherlands & $-4,20$ & 0,80 & 1,10 & $-1,40$ & $-0,40$ & 1,10 & 1,50 & 1,70 & 2,30 & 1,80 \\
Portugal & $-3,20$ & 1,70 & $-1,60$ & $-3,70$ & $-0,40$ & 1,30 & 2,20 & 2,30 & 3,80 & 3,00 \\
Spain & $-4,60$ & $-0,30$ & $-1,20$ & $-3,00$ & $-1,10$ & 1,70 & 3,90 & 2,90 & 2,80 & 2,00 \\
\hline \multicolumn{1}{l}{ Soutrce }
\end{tabular}

Source: developed by the author based on (Eurostat Data, Main GDP aggregates per capita, 20092018).

To confirm or refute the hypothesis about the impact of dynamics of health care financing on economic growth we calculated the corresponding correlation coefficients. Previously we checked whether the indicators of total expenditure for health care (TE), and in particular government financing and compulsory contributory health care financing (GF), voluntary health care financing (VF), and household out-of-pocket payment for health care (HP) obey the law of normal distribution based on the results of Shapiro-Wilk test (Table 6). Calculations were made in the STATA software.

Table 6. The results of the Shapiro-Wilk test regarding the subordination of indices of health care financing to the normal distribution

\begin{tabular}{|c|c|c|c|c|c|c|c|c|c|}
\hline & W & V & z & Prob>z & & W & V & $\mathbf{z}$ & Prob>z \\
\hline \multicolumn{5}{|c|}{ Austria } & \multicolumn{5}{|c|}{ Belgium } \\
\hline TE & 0.80741 & 2.968 & 2.101 & $0.01783^{*}$ & TE & 0.98744 & 0.193 & -2.438 & 0.99262 \\
\hline GF & 0.83366 & 2.563 & 1.786 & $0.03703^{*}$ & GF & 0.94095 & 0.910 & -0.160 & 0.56363 \\
\hline VF & 0.92697 & 1.125 & 0.205 & 0.41879 & VF & 0.90341 & 1.489 & 0.710 & 0.23871 \\
\hline HP & 0.84484 & 2.391 & 1.641 & 0.05042 & HP & 0.87295 & 1.958 & 1.236 & 0.10820 \\
\hline \multicolumn{5}{|c|}{ Cyprus } & \multicolumn{5}{|c|}{ Denmark } \\
\hline TE & 0.89510 & 1.617 & 0.865 & 0.19340 & TE & 0.93249 & 1.040 & 0.068 & 0.47286 \\
\hline GF & 0.96396 & 0.555 & -0.954 & 0.82988 & GF & 0.97767 & 0.344 & -1.660 & 0.95150 \\
\hline VF & 0.90401 & 1.479 & 0.699 & 0.24230 & VF & 0.93407 & 1.016 & 0.027 & 0.48908 \\
\hline HP & 0.91157 & 1.363 & 0.548 & 0.29196 & $\mathrm{HP}$ & 0.84006 & 2.465 & 1.704 & $0.04420 *$ \\
\hline \multicolumn{5}{|c|}{ Estonia } & \multicolumn{5}{|c|}{ Finland } \\
\hline TE & 0.91665 & 1.284 & 0.440 & 0.32990 & TE & 0.88565 & 1.762 & 1.030 & 0.15139 \\
\hline
\end{tabular}




\begin{tabular}{|c|c|c|c|c|c|c|c|c|c|}
\hline & & & & & & & & \multicolumn{2}{|c|}{ Continued Table 6} \\
\hline GF & 0.92637 & 1.135 & 0.220 & 0.41311 & GF & 0.88341 & 1.797 & 1.068 & 0.14277 \\
\hline VF & 0.97213 & 0.430 & -1.340 & 0.90983 & VF & 0.91010 & 1.385 & 0.578 & 0.28168 \\
\hline HP & 0.95179 & 0.743 & -0.495 & 0.68974 & HP & 0.87668 & 1.900 & 1.177 & 0.11951 \\
\hline \multicolumn{5}{|c|}{ France } & \multicolumn{5}{|c|}{ Germany } \\
\hline TE & 0.95401 & 0.709 & -0.571 & 0.71602 & TE & 0.98118 & 0.290 & -1.899 & 0.97119 \\
\hline GF & 0.80951 & 2.936 & 2.077 & $0.01891^{*}$ & GF & 0.96887 & 0.480 & -1.176 & 0.88016 \\
\hline VF & 0.70799 & 4.500 & 3.062 & $0.00110 *$ & VF & 0.84661 & 2.364 & 1.617 & 0.05293 \\
\hline HP & 0.78597 & 3.298 & 2.334 & $0.00979 *$ & HP & 0.88296 & 1.804 & 1.075 & 0.14111 \\
\hline \multicolumn{5}{|c|}{ Greece } & \multicolumn{5}{|c|}{ Hungary } \\
\hline TE & 0.90100 & 1.526 & 0.756 & 0.22470 & TE & 0.93978 & 0.928 & -0.127 & 0.55052 \\
\hline GF & 0.87224 & 1.969 & 1.247 & 0.10616 & GF & 0.95879 & 0.635 & -0.745 & 0.77198 \\
\hline VF & 0.95243 & 0.733 & -0.517 & 0.69727 & VF & 0.92851 & 1.102 & 0.168 & 0.43340 \\
\hline HP & 0.95911 & 0.630 & -0.758 & 0.77566 & HP & 0.97189 & 0.433 & -1.327 & 0.90778 \\
\hline \multicolumn{5}{|c|}{ Lithuania } & \multicolumn{5}{|c|}{ Netherlands } \\
\hline TE & 0.89018 & 1.692 & 0.953 & 0.17038 & TE & 0.90374 & 1.483 & 0.704 & 0.24070 \\
\hline GF & 0.86761 & 2.040 & 1.318 & 0.09375 & GF & 0.95107 & 0.754 & -0.471 & 0.68122 \\
\hline VF & 0.93845 & 0.949 & -0.090 & 0.53589 & VF & 0.97241 & 0.425 & -1.355 & 0.91224 \\
\hline HP & 0.96904 & 0.477 & -1.184 & 0.88176 & HP & 0.96815 & 0.491 & -1.141 & 0.87315 \\
\hline \multicolumn{5}{|c|}{ Portugal } & \multicolumn{5}{|c|}{ Spain } \\
\hline TE & 0.92808 & 1.108 & 0.178 & 0.42925 & TE & 0.88761 & 1.732 & 0.997 & 0.15936 \\
\hline GF & 0.86031 & 2.153 & 1.426 & 0.07696 & GF & 0.89548 & 1.611 & 0.858 & 0.19531 \\
\hline VF & 0.77392 & 3.484 & 2.458 & $0.00698 *$ & VF & 0.96177 & 0.589 & -0.863 & 0.80587 \\
\hline HP & 0.92628 & 1.136 & 0.222 & 0.41234 & HP & 0.92468 & 1.161 & 0.259 & 0.39766 \\
\hline
\end{tabular}

* - outside the normal distribution

Source: developed by the author using STATA software package.

Then we calculated the Pearson correlation coefficient (the normal distribution, the result of ShapiroWilk test $>0,05$ ) or Spearman correlation coefficient (indices are outside the normal distribution, the result of Shapiro-Wilk test $<0,05$ ) to define the statistical significance and strength of the relationship between investigated indices. Also, we determined the correlation coefficients considering the time lags to increase the adequacy of investigated indices.

Table 7 shows the summarized results of the impact of the dynamics of health care financing (in general and by different schemes) on the change of economic growth (GDP per capita).

Table 7. The statistical significance and strength of the impact of the dynamics of health care financing and the change of GDP per capita

\begin{tabular}{|c|c|c|c|c|c|c|c|c|}
\hline \multirow[b]{2}{*}{ Country } & \multicolumn{2}{|c|}{ TE } & \multicolumn{2}{|c|}{ GF } & \multicolumn{2}{|c|}{ VF } & \multicolumn{2}{|l|}{$\mathrm{HP}$} \\
\hline & Coefficient & $\begin{array}{c}\text { Time } \\
\text { lag }\end{array}$ & Coefficient & $\begin{array}{c}\text { Time } \\
\text { lag }\end{array}$ & Coefficient & $\begin{array}{c}\text { Time } \\
\text { lag }\end{array}$ & Coefficient & $\begin{array}{c}\text { Time } \\
\text { lag }\end{array}$ \\
\hline Austria & 0.8469 & 2 & 0.8571 & 2 & 0.7779 & 3 & 0.8033 & 3 \\
\hline Belgium & 0.6904 & 3 & 0.6372 & 3 & 0.6872 & 2 & -0.3882 & 0 \\
\hline Cyprus & 0.9500 & 2 & -0.9063 & 1 & 0.8682 & 1 & 0.9214 & 1 \\
\hline Denmark & -0.7914 & 3 & -0.5772 & 0 & 0.8473 & 2 & -0.9258 & 0 \\
\hline Estonia & 0.7767 & 2 & 0.8569 & 2 & 0.5642 & 2 & 0.3841 & 3 \\
\hline Finland & 0.9589 & 3 & 0.9462 & 3 & 0.8936 & 3 & 0.6056 & 1 \\
\hline France & 0.8369 & 3 & 0.9910 & 1 & 0.9000 & 3 & -0.9162 & 1 \\
\hline Germany & 0.5021 & 1 & 0.3945 & 2 & -0.4750 & 3 & 0.5251 & 1 \\
\hline Greece & -0.9128 & 1 & -0.8868 & 1 & 0.9225 & 3 & 0.5740 & 0 \\
\hline Hungary & -0.7290 & 1 & -0.7688 & 1 & -0.7449 & 1 & -0.4886 & 1 \\
\hline Lithuania & 0.9287 & 2 & 0.8739 & 2 & 0.4119 & 3 & $-0.2171^{*}$ & 1 \\
\hline
\end{tabular}




\begin{tabular}{lcccccccc} 
& \multicolumn{1}{c}{ Continued Table 7 } \\
\hline Netherlands & 0.8820 & 3 & 0.6738 & 3 & -0.7054 & 1 & 0.8674 & 3 \\
Portugal & -0.8958 & 3 & -0.9479 & 2 & 0.6736 & 0 & 0.4749 & 0 \\
Spain & -0.5817 & 1 & -0.9070 & 2 & 0.8001 & 2 & 0.8762 & 3 \\
\hline
\end{tabular}

* the effect is statistically insignificant in case of acceptable calculations (time lag from 0 to 3 years)

Source: developed by the author using STATA software package.

In this research we supposed the impact is not significant in case of a weak relationship (a correlation coefficient $<0,3$ ). Average influence is in case of a correlation coefficient from 0,3 to 0,5 , high - from 0,5 to 0,7 , and very high - more than 0,7 .

Also, the correlation analysis of the relationship between the dynamics of total expenditure for health care and the change of economic growth in these countries grounded the duration of time lags of statistical significance of investigated indices: very high - in Greece and Hungary (with a lag of 1 year), in Austria, Cyprus, Estonia, and Lithuania (with a lag of 2 years), in Belgium, Denmark, Finland, Netherlands, Portugal and France (with a lag of 3 years) and high - in Germany and Spain (with a lag of 1 year). The impact character for 9 countries is direct, for 5 countries - inverse.

In particular, the correlation analysis of the impact of the dynamics of government financing and compulsory contributory health care financing, voluntary health care financing, household out-of-pocket payment for health care on the change of GDP per capita grounded the duration of time lags of statistical significance of investigated indices:

- for government health care financing: very high - in France, Cyprus, Greece, and Hungary (with a lag of 1 year), in Austria, Estonia, Lithuania, Spain and Portugal (with a lag of 2 years), high - in Denmark (without a time lag), in Belgium, Finland and Netherlands (with a lag of 3 years), average - in Germany (with a lag of 2 years). The impact character for 8 countries is direct, for 6 countries - inverse;

- for voluntary health care financing: very high - in Hungary, Cyprus, and Netherlands (with a lag of 1 year), in Denmark and Spain (with a lag of 2 years), in Austria, Finland, Greece, and France (with a lag of 3 years), high - in Portugal (without a time lag), in Belgium and Estonia (with a lag of 2 years), average - in Germany and Lithuania (with a lag of 3 years). The impact character for 11 countries is direct, for 3 countries - inverse;

- for household out-of-pocket payment for health care: very high - in Denmark (without a time lag), in France and Cyprus (with a lag of 1 year), in Austria, Netherlands, and Spain (with a lag of 3 years), high - in Greece (without a time lag), in Finland and Germany (with a lag of 1 year), average - in Belgium and Portugal (without a time lag), in Hungary (with a lag of 1 year), in Estonia (with a lag of 3 years). The impact character for 9 countries is direct, for 5 countries - inverse.

Therefore, we prove the hypothesis about the positive impact of health care financing on the economic growth.

Conclusions. In this research we analysed the structure of health care financing, in particular financing schemes, main providers, and health care functions for the sample from 14 EU countries for 2009-2018. The top countries in health care financing were identified. They are Germany, France, Austria, Belgium, and Denmark (the share of the expenditure is more than 10\% of GDP). Using the STATA software package, the nature of the investigated indices distribution was estimated based on Shapiro-Wilk test, the results of which made it possible to choose the method to calculate the correlation coefficient Pearson or Spearman. The correlation analysis of the impact of the dynamics of total expenditure for health care on the change of GDP per capita confirmed the hypothesis that health care financing is an important factor of economic growth. We determined the time lags, when this impact is statistically significant: very high - in 12 from 14 investigated EU countries (with a lag of 1-3 years) and high in 2 from 14 countries (with a lag of 1 year). The character of this relationship for the most countries (9 from 14 
countries) is direct (positive), and for 5 countries it is inverse (negative). Separately we showed the results of the correlation analysis of the relationship between the dynamics of government financing and compulsory contributory health care financing, voluntary health care financing, household out-of-pocket payment for health care and the change in GDP per capita. For the most countries the relationship is statistically significant with very high or high impact and positive effect. The time lags differ from 0 to 3 years. So, we proved the hypothesis about the positive impact of health care financing on the economic growth in a country, and it will be deeper developed in future research.

Author Contributions: conceptualization, A.S. and R.K.; methodology, A.S.; software, A.S.; validation, A.S. and R.K.; formal analysis, A.S.; investigation, A.S.; resources, A.S.; data curation, A.S.; writing-original draft preparation, A.S.; writing-review and editing, A.S. and R.K.; visualization, A.S.; supervision, A.S.; project administration, A.S.

Funding: This research received no external funding.

\section{References}

Alkaravani, B. T. (2014). Marketing research of medical services quality. Marketing and management of innovations, 1, 124131. Retrieved from: [Link]

Antosova, I., Hazuchova, N., \& Stakova, J. (2019). Market Segmentation in Healthcare. Marketing and Management of Innovations, 3, 151-166. [Google Scholar] [CrossRef]

Bagmet, K., \& Obeid, H. (2017). Financing social protection in Ukraine and the European Union: current situation and prospects. SocioEconomic Challenges, 1 (1), 54-59. [Google Scholar] [CrossRef]

Cylus J., Permanand, G., \& Smith, P.C. (2018). Making the economic case for investing in health systems: What is the evidence that health systems advance economic and fiscal objectives? Policy brief. the WHO Regional Office for Europe, Denmark. [Google Scholar]

Eurostat Data. Expenditure for selected health care providers by health care financing schemes. Retrieved from [Link]

Eurostat Data. Main GDP aggregates per capita. Retrieved from [Link]

Eurostat. (2020). Consolidated quality report on healthcare expenditure and financing statistics. Luxembourg: Publications Office of the European Union. [CrossRef]

Fan, V. Y., \& Savedoff, W. D. (2014). The health financing transition: a conceptual framework and empirical evidence. Social science \& medicine, 105, 112-121. [Google Scholar] [CrossRef]

Musgrove, P. Public and provate roles in health: theory and financing patterns. In Public and provate roles in health: theory and financing patterns (pp. 79-79). [Google Scholar]

Pearson, K. (1896). Mathematical contributions to the theory of evolution-III. Regression, heredity, and panmixia. Philosophical Transactions of the Royal Society of London, Series A 187, 253-318.[Google Scholar]

Schieber, G., Baeza, C., Kress, D., Maier, M., Jamison, D., Breman, J., \& Measham, A. (2006). Health financing systems in the 21st century. Disease Control Priorities in Developing Countries. 2nd edition (New York: Oxford University Press) pp, 225-242. [Google Scholar] [CrossRef] Scholar]

Shapiro, S., \& Wilk, M. (1965). An analysis of variance test for normality (complete samples). Biometrika, 52, 591-611. [Google

Spearman, C. E. (1904). The proof and measurement of association between two things. American Journal of Psychology, 15 , 72-101.[Google Scholar]

Stepovic, M. (2019). GDP Growth and Health Care Expenditures Worldwide. Wentham Open. 7, 9-18. https://doi.org/10.2174/1874129001907010009

White, B. (2001). The Future of Health Care Financing. Fam Pract Manag, 8(1), 1-36. Retrieved from: https://www.aafp.org/fpm/2001/0100/p31.html

WHO (n. d.). Health systems: key expected results. Retrieved from: https://www.who.int/healthsystems/about/progresschallenges/en/

Yelnikova, J., \& Kwilinski, A. (2020). Impact-Investing in The Healthcare in Terms of the New Socially Responsible State Investment Policy. Business Ethics and Leadership, 4(3), 57-64. https://doi.org/10.21272/bel.4(3).57-64.2020.

А. В. Самойлікова, к.е.н., Сумський державний університет (Україна).

Р. Кунєв, директор, TOB «Vazhod-2019» (Болгарія)

Вплив фінансування охорони здоров'я на економічне зростання: аналіз країн $€ \subset$

У цій роботі узагальнено сучасні тенденції та актуальні особливості фінансування охорони здоров'я. Основна мета 
дослідження - дослідити динаміку фінансування охорони здоров'я як факторе економічного зростання на основі аналізу країн ЄС. Систематизація літературних джерел та підходів до вирішення проблеми фрінансування охорони здоров'я та його структури свідчить про те, що аналіз динаміки фінансування охорони здоров'я та його впливу на економічне зростання в країнах ЄС проводився фррагментарно. Актуальність вирішення цієї наукової проблеми полягає в тому, що це питання досіє актуальним як для науковців, так і для політиків, особливо для України на основі європейського досвіду. Дослідження теми в роботі здійснюється в такій логічній послідовності: 1) вступ та обгрунтування актуальності; 2) огляд літератури та виявлення необхідності дослідження у цій науковій галузі; 3) опис методології, методів дослідження та поточної гіпотези; 4) характеристика результатів дослідження та підтвердження гіпотези про позитивний вплив фінансування охорони здоров'я на економічне зростання; 5) надання висновків. Методологічними інструментами методів дослідження були структурний та порівняльний аналіз, логічне узагальнення та наукова абстракція. Методи міждержавного статистичного та аналітичного аналізу з використанням програмного пакету Excel 2010 для вибірки з 14 країн ЄС на 2009-2018 роки (обмежена кількість країн та обмежені дані 2018 роком через наявність інфрормації на відкритому інформаційному порталі статистичного офісу Європейського Союзу) були застосовані для аналізу структури фрінансування охорони здоров'я, зокрема схем фрінансування, основних постачальників та функцій охорони здоров'я. Були визначені топові країни у фінансуванні охорони здоров'я. Для підтвердження гіпотези про позитивний вплив фінансування охорони здоров'я на економічне зростання - динаміку ВВП на душу населення застосовувались методи емпіричного аналізу із використанням програмного пакету STATA для цієї вибірки країн ЄC. Характер розподілу досліджуваних показників оцінювали за допомогою критерію Шапіро-Вілка, за результатами якого було обрано розрахунковий метод коефбіцієнта кореляції (Пірсона або Спірмена). Сила та характер взаємозв'язку між показниками загальних витрат на охорону здоров'я, зокрема державним фінансуванням, обов'язковими внесками на фінансування охорони здоров'я, добровільним фінансуванням охорони здоров'я, виплатою домогосподарствами коштів за охорону здоров'я та динамікою ВВП на душу населення були встановлені за допомогою кореляційного аналізу. Він виявив тривалість часових лагів, через які цей взаємозв'язок є найбільш статистично значущим. Результати дослідження показують, що вплив фінансування охорони здоров'я на економічне зростання країни є дуже високим у 12 із 14 досліджуваних країн ЄС (із лагом 1-3 роки) та високим у 2 із 14 країн (із лагом 1 рік). Характер цих відносин для більшості країн (9 із 14 країн) є прямим (позитивним), а для 5 країн - зворотним (негативним). Результати дослідження будуть корисні під час майбутніх фундаментальних та практичних досліджень, пов'язаних з фінансуванням охорони здоров'я та його моделюванням, для науковців та державних службовців для реформування системи охорони здоров'я та ії фінансового механізму.

Ключові слова: ВВП на душу населення, витрати на охорону здоров'я, державне фінансування охорони здоров'я, добровільне фінансування охорони здоров'я, домогосподарства, економічне зростання, медичне страхування, охорона здоров'я, постачальник медичної допомоги.

Manuscript received: 04.09.2020

(c) The author(s) 2020. This article is published with open access at Sumy State University. 